\title{
Exploration in Classroom Teaching of "Introduction to the Basic Principles of Marxism" in Universities
}

\author{
Li Zeng \\ College of Politics, Sichuan Agricultural University \\ Ya'an 625014, Sichuan, China \\ E-mail: cndzl@yahoo.cn
}

Received: October 10, 2011

Accepted: November 10, $2011 \quad$ Published: December 1, 2011

doi:10.5539/ass.v7n12p206

URL: http://dx.doi.org/10.5539/ass.v7n12p206

Foundation Item: Double Support Project of Sichuan Agricultural University in 2010 --- College-Level Special Project

\begin{abstract}
In order to have a systematic theoretical education of Marxism among university students, help university students master the world outlook and methodology of Marxism, set up Marxism's outlook on life and sense of worth, learn to use the world outlook and methodology of Marxism to observe and analyze problems and cultivate and improve university students' capacity in applying Marxism theory to analyze and resolve actual problems, teachers have to have positive exploration in the classroom teaching in teaching of "Introduction to the Basic Principles of Marxism" in colleges and universities, based on human-orientation, establish teachers' leading role and students' subject position, change the traditional concepts, realize three changes in the process of teaching, keep pace with the times, continuously update means of teaching, connect theory with reality, reflect the methodology significance of courses and enhance effectiveness of the classroom teaching of "Introduction to the Basic Principles of Marxism".
\end{abstract}

Keywords: Introduction to the basic principles of Marxism, Classroom teaching, Exploration

Since the basic principles of Marxism are of high generality and abstractness, it is generally felt among university students that this course is abstract and difficult to comprehend. As a result, university students step back at the sight of this course and are weary of studying, which greatly constrains improvement of teaching effect and affects improvement of the teaching quality of this course. Thus, how to enhance effectiveness of "Introduction to the Basic Principles of Marxism" (hereinafter referred to as "Principles"), and how to make this course one that students really favor and benefit a lot all their life-long is a topic which is worth to be deeply studied and explored. With teaching practice for several years, the author of this paper believes that, as a teacher of the course of "Principles" in the colleges and universities, one has to make efforts from the following several aspects in the process of classroom teaching.

\section{To establish the leading role of teachers and subject position of students based on human-orientation}

The Seventeenth Congress of CPC pointed out that, the "core" of the scientific outlook on development was "human-orientation". (Hu Jintao, 2007) In order to carry out the spirit of the Party Central Committee, it is required that teachers of the course of "Principles" in colleges and universities to insist in "human orientation" in the process of teaching.

The traditional "Principles" course teaching is centered by teachers, which emphasizes that in the process of teaching, teachers have to play a leading role and it is teachers who determine the pattern, method, content, organization and so on of teaching, while students are marginalized in the process of teaching, totally in a subordinate status and having no other choice but to passively accept what are given to them. At the same time, in the process of real teaching, teachers turn a blind eye to students' consciousness and initiative in learning, believing that students are the container to receive knowledge, so they offer unidirectional "indoctrination" of knowledge to students. Teaching of this kind of mode causes the "teaching" of teachers to be emphasized, but the "learning" of students to be ignored, which affects enthusiasm, initiative and creativity of students in the process 
of learning, ignores that students are the internal factor and direct motive of the course learning and leads to a passive situation with low teaching efficiency.

In order to change this situation, teachers are required to attach great importance to the subject position of students in the process of teaching, deem students as people having their own opinions, their own thought and emotion, so as to enable students' initiative, enthusiasm and innovation to be fully tapped. Since the interaction of the teaching process is realized by the two social subjects together --- teachers and students, the fundamental factor of the teaching process is human. As both teachers and students have initiative, enthusiasm and innovation, in the process of teaching, we should not only affirm the leading role played by the teachers, but also attach great importance to the subject position of students. Teaching of teachers to students is an external factor, and active initiative of students is the internal factor. An external factor can't function without an internal factor. As an old saying goes, "No man is his craft's master the first day". The knowledge taught by teachers can only be internalized into their own morality and capacity of students through students' reflection, apprehension and conscious application as well as combination with the reality. Spranger definitely pointed out that, "Education does not absolutely refer to pure cultural transmission. The reason why education is called education is that it is able to awaken people's personality and soul, where lies the core of education." (Zou Jin, 1988) Therefore, the starting point and ultimate goal of teaching of the "Principles" course is to attach great importance to the internal demand of students' learning in the process of the entire teaching activity, to mobilize and stimulate students' enthusiasm, initiative and innovation in learning, and make them have good political quality and high theoretical quality, which can achieve the teaching purpose of "Introduction on the Basic Principles of Marxism". The US Psychologist Rogers proposed abolishing the traditional role of teachers and replace it with the concept of facilitator. The task of a facilitator is to provide all varieties of learning resources, to offer a sort of atmosphere to promote learning of students and to enable students to know how to learn. Simply speaking, Rogers advocated abolishing teacher-center and advocated student-center. The key of student-center is to endow learning with an individual significance, which, essentially, is to fully reflect the subjective initiative of students. The stronger the subjective consciousness of students, the higher their self-consciousness to participate in education activities and the more possible it is for them to tap their own initiative, enthusiasm and innovation in the process of education. This requires education to combine the leading role of educators together with the subject role of students.

Hence, we have to change the teaching modes of "knowledge center" and "teacher center", insist on human orientation in the process of teaching of "Principles" and set up a corresponding modern teaching mode. Human orientation in the teaching of the course of "Principles" means that teachers ought to regard students as the starting point of teaching in the teaching process of the course, regard characteristics of students' physical and psychological development, students' knowledge foundation, interest, capacity level and development need as well as students' internal natural attribute as the precondition and evidence of teaching, deem students as the subject of their own development and encourage students to facilitate their overall development through initiative learning. (Xiao Fang, 2005)

\section{To change the concept and to realize three changes in the process of teaching}

Since teachers are the dominant players of the classroom teaching of "Principles" and students are the subjects, it is required that teachers have to complete the following several aspects in the process of teaching.

In the first place, change of the teaching mode --- change from indoctrinization of students to active learning of students. The US well-known educator Bloom believed that, acquisition of knowledge is an active process, in which learners are not passive receiver of information, but active participant of the process of knowledge acquisition. The optimization teaching process of the course of "Principles" has to change the former unidirectional indoctrinization adopted by teachers, a teaching mode with the center of imparting knowledge of "teaching and resolving confusion". In the process of teaching, emphasis on active learning of students is not to negate the leading role of teachers in the process of teaching, but to achieve such a purpose --- to make teachers come to understand that they should determine corresponding teaching starting point according to the actual situation of students in the process of teaching. In all the aspects of the teaching process, emphasis of "preparing a lesson" should be placed upon analysis and understanding of students, emphasis of "teaching" should be placed upon guidance of students' learning methods and emphasis of "examination" should be placed upon testing students' ability to connect theory with practice and innovative thinking.

In the second place, change of the teaching concept --- change from the teaching concept centered by textbook knowledge to the teaching concept based on development of students. In the process of teaching of the "Principles" in colleges and universities, emphasis on orientation of development of students is not to emphasize that teachers do not teach textbook knowledge in the process of teaching, but to emphasize that teachers ought to 
realize combination of teaching of textbook knowledge and personal, comprehensive and harmonious development of students. Thus, in the process of teaching of the "Principles", "knowledge of teaching and learning" should be converted to "subject knowledge of teachers". In the process of teaching, "subject knowledge of teachers" is then converted to "knowledge of students" and "knowledge and students" gets "generated and grown".

In the mean while, since the young students are at a stage of great thirst for knowledge on the university campus, but they have rare direct contact with the society, especially those engineering students, they are lacking in some necessary knowledge in social sciences. Therefore, in the process of teaching, students often feel difficult in grasping some knowledge. Then, it is necessary to introduce relevant knowledge at the time of explaining the theory. For instance, at the time when teachers explain about conditions for labor force to become commodities, they may guide students to come to realize that in the socialism situation in China, so long as laborers do not possess the conditions for independent producers, the labor force might become commodities. Furthermore, teachers may take into consideration the development of the labor force market in China, which can enable students to have a more profound understanding. Of course, we can also invite some well-known experts and scholars to give a special lecture so as to enable students to be able to come to understand the dynamic development condition of the contemporary world and relevant knowledge, achieve the purpose of enriching students' scope of knowledge and strengthen the effictiveness of teaching.

In the third place, change of the teaching process --- change from a static teaching to a dynamic teaching. Teaching is a dynamic process, so teachers who teach the course of "Principles" in colleges and universities have to make appropriate adjustment according to the actual situation of students in learning. In the process of specific teaching practice, as a result of the development of the era and changes of practice, the teaching starting point and teaching difficult points that are formerly designed may not be able to adapt to the changing situation. Hence, it is necessary to make adjustment on specific teaching content according to specific teaching content so as to enable teaching to have a promotive effect upon overall and harmonious development of students. For example, when teachers teach about the rule of unity of opposites, and when they teach about identity and militancy of contradiction and functioning of dialectic relations principle in development of objects, we have to take into consideration the proposal of the country that is put forward currently for construction of a harmonious socialist society and world and emphasize that harmony should become the requirement of the times by construction of the socialist society. However, harmony is the unity of sameness and diversity in the combat. To pursue harmony is neither to avoid contradiction and to seek for virtue and false sameness, nor to enlarge opposition or to generate contradiction, but to search for common points while reserving differences, and to handle all sorts of interest relations and conciliate contradictions in an appropriate way. In this way, at the time when students come to realize existence of contradiction, they can also attach importance to harmonious development.

\section{To keep pace with the times and to continue to update teaching means}

Since different subjects are different in the teaching content, and the teaching method and teaching means will also be distinguished. Thus, only if we carefully grasp the knowledge structure system and specific theoretical content of the subjects, can we carry out corresponding teaching method and teaching means, and can the purpose of improving classroom teaching effects be achieved.

The traditional teaching means of chalk plus blackboard is relatively intuitive, so it is likely to be accepted by students. In the process of teaching, students are able to grasp the content taught by teachers in an accurate way and have a clear idea about the thought of teachers in how to put forward a question, analyze the question and resolve the question. When teachers write on the blackboard, the brain of students also follows in thinking, which is likely to mobilize the thinking capacity of students and leave a deep impression on their learning. According to these characteristics, teachers may write some difficult content that is involved in the course on the blackboard, so as to have a discussion in the class according to the specific reaction of students. Students can ask a question at any time and teachers should answer the question in time to make students' understanding more thorough.

As for the course of "Principles", we advocate using computer-assisted instruction (CAI) multi-media teaching. Pictures, words and sheets manifested with CAI are vivid, intuitive and convenient to use, which is unlikely to be achieved in the teaching with the traditional means of blackboard plus chalk. In the process of teaching, teachers may resort to all sorts of pictures and combine with the content to be taught, which can enable the teaching to be more vivid and intuitive. Furthermore, text complete with pictures can reduce baldness of the course. We can also resort to phonotape and videotape media data to strengthen infection of the course and impression of students upon the learning content. For instance, when the teachers teach about the first chapter about the 
material feature and developmental rule of the world, they can first of all play a section of "Cosmos and Man", a science education film jointly produced by Beijing Science and Education Film Studio and the film channel programming center of the State Administration of Radio Film and Television, to let students have an initial idea about the secret issues of the material world: what on earth the cosmic material is, how the material moves, which power manipulates these movements, how these movements start and how these movements continue until today. In this way, in the course of explaining specific content, students' understanding and knowledge will be more profound. At the same time, there is no need to use the blackboard, teachers may save a lot of time, which allows teachers to explain more knowledge to students within a short period of time, reflect more excellence of the multi-media teaching and get the teaching resources optimized.

\section{To link theory with practice and to reflect the methodology significance of the course of "Introduction to the Basic Principles of Marxism}

Professor Gu Hailiang pointed out, ideological and political theory courses in colleges and universities should be keen and innovative, with content closer to the life reality, thinking reality and learning reality of contemporary university students and closer to reality of university students' growth in the future and should practically strengthen effectiveness of the ideological and political theory courses. (Gu Hailiang, 2005) This is an issue that is difficult to resolve in theoretical teaching, and is more a challenge all the time especially for teachers who teach the course of "Principles" in colleges and universities. In their junior middle school and senior middle school, students have learnt a certain amount of relevant political theory courses, so if the university teachers still adopt the teaching method of "cramming method", namely, theoretical explanation in the college course teaching, then it is likely that the psychological inversion phenomenon may happen among students. Thus, in the process of teaching, we have to concentrate on connecting theory with practice as this is a very important aspect. Specifically, we ought to realize the following several aspects.

First of all, teaching of teachers ought to realize linking theory with practice. This requires teachers to take into consideration some realistic issues in the current world in the process of teaching and make necessary analysis by combining the theoretical knowledge they teach. Marxism is a guide to our action, so it has to in compliance with our reality. However, a gap exists between theory, policy and practice. Hence, we need to offer correct guidance to our students in the teaching. For instance, some students are lacking in a correct understanding in the concept of capital, so teachers ought to place special emphasis on its duality in the process of teaching, namely the natural attribute and the social attribute. The natural attribute has no social feature at all, without any value critical standard, so it exists both in the society of socialism and capitalism, and belongs to the scope of the market economy. By contrast, social attribute has the value critical standard and falls within the scope of production elements. This is able to deepen students' understanding in this concept. In addition, considering some current hot issues, such as, high housing price, "difficulty in seeing a doctor and high price in seeing a doctor", foodstuff safety and environmental issue, etc, may strengthen students' understanding in these theories.

However, it is necessary to prevent and overcome some incorrect practice in linking theory with practice. The course of "Introduction to the Basic Skills of Marxism" is one of the major channels and battlefields in the ideological and political theory courses in colleges and universities, so its platform should be serious. It is also different from other occasions, so $t$ teachers have to pay attention to the objective effect in their teaching of this course. Some individual teachers may run off at the mouth in analyzing some significant principle issues in linking theory with practice in order to pursue their own purposes or cater to students. These individual teachers may express their own opinions or viewpoints at will, which leads to quite negative influences from an objective perspective, and which needs to be prevented and noticed. In the process of teaching, teachers should not only have the courage to emancipate their mind, be bold enough to make explorations and disclose the dark side of the society, but also should be good at offering positive guidance to students, insist on making matter-of-fact analysis and study of relevant theoretical issues and realistic issues with the standpoint, viewpoint and method of Marxism, and attempt to realize systematic and scientific teaching theory and accurate, novel and healthy in linking theory with practice.

Then, learning of students ought to realize linking theory with practice. In the practical operation, students are requested to go outside the campus. That is to say, they are required to go in for social practice so as to enable students to really realize combination of the theory learnt with practice. On one hand, this can help students come to understand the society, correct their own knowledge and achieve unification of subjectivity and objectivity. On the other hand, this can cultivate the excellent quality of enduring hardships and being capable of hard work and realize unification of knowing and doing. In practical operation, teachers may adopt the following procedures. Firstly, teachers prescribe some social practice subjects (scopes) for students and ask them to select a subject they consider suitable for themselves and fill in a thesis proposal and design a questionnaire and 
interview topic to submit to the teachers for check and approval. Secondly, students may get involved in a specific social practice and begin with a social practice report. Finally, students may have an exchange defense on the report and assess the performance of social practice. Of course, this choice has not been widely put into effect so far due to constraint of funds and other factors. This is a quite important aspect, without which students are unlikely to learn to meet practical needs.

In one word, through efforts of teachers, students and the schools, the classroom teaching of the course of "Principles" can necessarily play its role as the major channel and major battlefield in the ideological and political theory courses in colleges and universities and will have positive effects on cultivating the world outlook of, outlook on life and methodology of contemporary university students.

\section{References}

Gu, Hailiang. (2005). Enhancing the Development of College Ideological and Political Theory Education on the Basis of Innovation. Journal of Ideological \& Theoretical Education, (11):32.

Report by $\mathrm{Hu}$ Jintao in the Seventeenth Congress of CPC. (2007). Xinhua Net. [Online] Available: http://www.Sina.com.cn, October 24.

Xiao, Fang. (2005). A Demonstration of the Thought of Taking Person for Basis in Constructing Teacher's Morality. Journal of Educational Science of Hunan Normal University, (5):50-51.

Zou, Jin. (1988). Summary of Spranger's Thought on Culture Pedagogy. Foreign Education, (3):55. 